\title{
Beta-lactamase resistance genes in Enterobacteriaceae from Nigeria
}

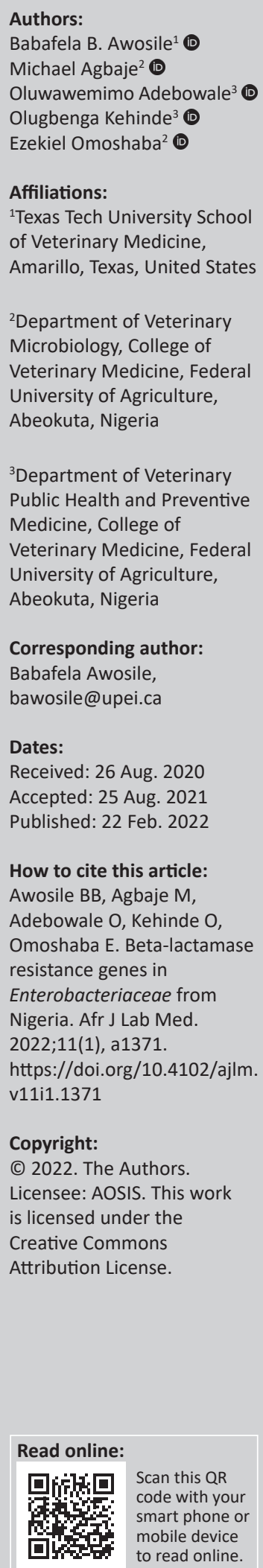

Background: Beta-lactamase genes are one of the most important groups of antimicrobial resistance genes in human and animal health. Therefore, continuous surveillance of this group of resistance genes is needed for a better understanding of the local epidemiology within a country and global dissemination.

Aim: This review was carried out to identify different beta-lactamase resistance genes reported in published literature from Nigeria.

Methods: Systematic review and meta-analysis was carried out on eligible Nigerian articles retrieved from electronic literature searches of PubMed ${ }^{\circledR}$, African Journals Online, and Google Scholar published between January 1990 and December 2019. The Preferred Reporting Items for Systematic Reviews and Meta-Analyses method was adopted to facilitate clarity and transparency in reporting review findings.

Results: Fifty-seven articles were included. All beta-lactamases reported were detected from Gram-negative bacteria, particularly from Enterobacteriaceae. Thirty-six different betalactamase genes were reported in Nigeria. These genes belong to the narrow-spectrum, AmpC, extended-spectrum and carbapenemase beta-lactamase resistance genes. The pooled proportion estimate of extended-spectrum beta-lactamase genes in Nigeria was 31\% $95 \%$ confidence interval [CI]: $26 \%-36 \%, p<0.0001$ ), while the estimate of the $b l a_{\text {CTX-M-15 }}$ gene in Nigeria was $46 \%$ (95\% CI: 36\% - 57\%, $p<0.0001)$. The proportion estimate of AmpC genes was 32\% (95\% CI: 11\% $-52 \%, p<0.001)$, while the estimate for carbapenemases was $8 \%(95 \%$ CI: $5 \%-12 \%, p<0.001)$.

Conclusion: This study provides information on beta-lactamase distribution in Nigeria. This is necessary for a better understanding of molecular epidemiology of clinically important beta-lactamases, especially the extended-spectrum beta-lactamases and carbapenemases in Nigeria.

Keywords: antimicrobial resistance; beta-lactamase gene; Nigeria; review; epidemiology.

\section{Introduction}

Beta-lactam antimicrobials are one of the most important groups of antimicrobial drugs used in both human and animal health. Antimicrobials such as extended-spectrum cephalosporins and carbapenems have been categorised by the World Health Organization as 'last resort' and 'critically important antimicrobials' because antimicrobial alternatives for treating last resort antimicrobial resistant bacteria is limited. ${ }^{1}$ However, resistance to last resort antimicrobials is occurring rapidly on a global scale. ${ }^{2}$ Most resistance to beta-lactams in Enterobacteriaceae is mainly due to the production of beta-lactamases, which are often encoded either on the chromosome or the plasmid. ${ }^{3,4}$ The production of beta-lactamases such as extended-spectrum beta-lactamases (ESBLs), AmpC beta-lactamases, and carbapenemase beta-lactamases have increasingly been detected globally in food and companion animals, wildlife, humans, and the environment. ${ }^{4,5}$ The dissemination of several beta-lactamase genes across different resistant bacterial populations from different hosts and environments illustrates that antimicrobial resistance (AMR) is a One Health challenge. ${ }^{6}$

Beta-lactamase production in Enterobacteriaceae is a public health concern due to the possibility of therapeutic failure, serious consequences for infection control and increased risk of morbidity and mortality in animals and humans. ${ }^{7}$ The predominant ESBL genes encountered are $b l a_{{\mathrm{CTX}-\mathrm{M}^{\prime}}} b l a_{\mathrm{TEM}^{\prime}}$ and $b l a_{\mathrm{SHV}}$. The prevalent AmpC beta-lactamase is $b l a_{\mathrm{CMY}-2^{\prime}}$ while for carbapenemases, $b l a_{\mathrm{OXA}-48}$ and $b l a_{\mathrm{NDM}-1}$ have been reported globally. ${ }^{5}$ Although beta-lactamase genes are globally disseminated, they are not equally prevalent among human and animal bacteria. Also, the occurrence and prevalence of these resistance genes varies across different geographic regions. For instance, 
while $b l a_{\mathrm{CTX-M-15}}$ is widely disseminated and has been reported in almost every region of the world, AmpC bla ${ }_{\mathrm{CMY}-2}$ has been mostly encountered in North America in both animal and human hosts. ${ }^{8}$

Therefore, there is a need for continuous surveillance of betalactamase resistance genes to better understand the local and global epidemiology of these genes. While detailed national AMR information exists for high-income European and North American countries through integrative surveillance, this is often lacking in most low- and middle-income African countries including Nigeria. Nigeria's AMR surveillance is in its infancy; thus, the generation of AMR data through the systematic review of published literature is still a useful tool that can give a glimpse of the AMR situation in Nigeria. This systematic review was carried out to identify the different beta-lactamase resistance genes reported in published Nigerian literature, to describe the distribution of these genes between animal, human and environmental settings, and to estimate the proportion of the different beta-lactamase resistance genes in Nigeria. This systematic review was conducted per the Preferred Reporting Items for Systematic Reviews and Meta-Analyses checklist. ${ }^{9}$

\section{Methods}

\section{Literature search and data sources}

The literature search was conducted in PubMed ${ }^{\circledR}$, Google Scholar and African Journals Online (AJOL) electronic databases using a combination of Boolean operators (AND, OR) and predefined keywords. We used the following terms for our search: beta-lactamases AND Nigeria OR betalactamase resistance genes AND Nigeria, bla $a_{\text {CTX-M }}$ AND Nigeria, $b l a_{\mathrm{TEM}}$ AND Nigeria, $b l a_{\mathrm{SHV}}$ AND Nigeria, $b l a_{\mathrm{OXA}}$ AND Nigeria, carbapenemases AND Nigeria, AmpC betalactamase resistance AND Nigeria, and ESBL resistance AND Nigeria. The search was limited to publications between January 1990 to December 2019. The primary aim of the review was to determine the distribution and different types of beta-lactamase genes circulating in Nigeria across the health sectors. Title screenings of the articles were done using the following eligibility criteria: (1) the study location must be Nigeria and (2) the study must have reported the detection of any type of beta-lactamase genes. Afterwards, an abstract review was done to determine the relevance of each article to the review's objectives and purpose. For an article to be included it must report the phenotypic antimicrobial susceptibility testing method used and the molecular techniques used to detect beta-lactamase resistance genes. Furthermore, a supplementary literature search was done by reviewing the references of eligible articles. Studies that reported beta-lactamase production based on phenotypic synergy test without molecular beta-lactamase gene detection were excluded from the review. Included articles were then sorted into qualitative and quantitative categories. All articles that reported the molecular detection of at least one betalactamase resistance gene were included in the qualitative, while studies with extractable data on the proportions of different types of beta-lactamase resistance genes from animals, humans and the environment were further considered for quantitative meta-analysis.

\section{Data extraction and analysis}

The data were extracted into a Microsoft Office Excel 2010 spreadsheet (Microsoft Corporation, Redmond, Washington, United States). For each eligible study, data extracted included: first author's details, publication year, sample type (animal faeces, retail meat products, human clinical samples, environmental samples), sample source (animal, human or environment) and study location or geopolitical zone. Also, the number and type of bacteria isolated, the beta-lactamase gene detected, the number of isolates phenotypically positive for the beta-lactamase production and the number of bacterial isolates genotypically positive for beta-lactamase genes were recorded. The antimicrobial susceptibility testing method (disc diffusion, broth microdilution, agar dilution, E-test or automated methods) and the beta-lactamase genotyping and phenotyping methods were noted. The proportion (with 95\% confidence interval [CI]) of each beta-lactamase gene as reported for each study was calculated by dividing the number of bacteria positive for the beta-lactamase gene by the total number of bacteria positive phenotypically or the total number of bacteria isolated depending on the data available.

Random effects meta-analysis was used to calculate the pooled (weighted) proportions for the different types of the beta-lactamase groups with $95 \%$ CIs. The analysis was done to allow for any heterogeneity between studies. Studies reporting a low number of bacterial isolates $(<10$ isolates) were not included in the meta-analysis. The pooled prevalence and each study's estimates were presented using forest plot. The $I^{2}$ statistic (a measure of inconsistency) was used to assess the variation between studies due to heterogeneity. A value of $0 \%$ means there was no observed heterogeneity; increasing values indicate increasing heterogeneity. The $I^{2}$ statistic with values $25 \%$ or less were subjectively considered as low, $26 \%-50 \%$ as moderate, and higher than $50 \%$ as substantial heterogeneity. Subgroup analysis was performed to account for potential sources of heterogeneity between studies. A separate meta-analysis was carried out for each of the dominant beta-lactamase groups. Statistical significance $(p)$ was set at 0.05 while statistical analysis was carried out using STATA SE version 15.0 (College Station, Texas, United States).

\section{Ethical considerations}

This article followed all ethical standards for research without direct contact with human or animal subjects.

\section{Results Study characteristics}

Systematic search from three electronic databases identified 567 articles (197 from PubMed ${ }^{\circledR}, 30$ from AJOL and 340 from Google Scholar) (Figure 1). A total of 510 articles were 


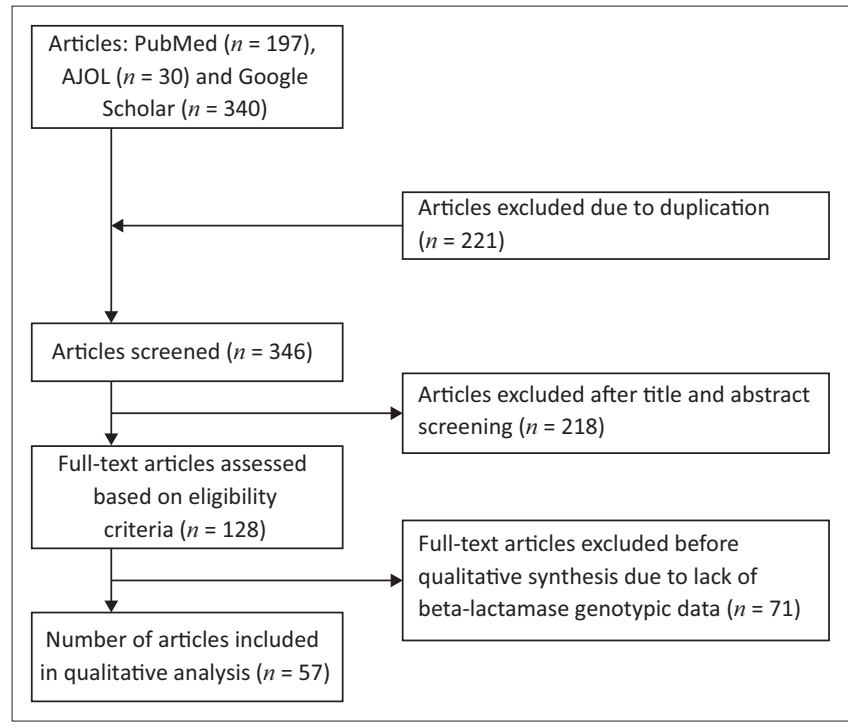

AJOL, African Journal Online.

FIGURE 1: Flow diagram summarising the process of literature search and selection.

excluded based on the selection criteria (Figure 1). Fifty-seven articles were included in the qualitative review, of which 11 were animal, 38 human and 8 environmental studies. For the animal studies, isolates were from poultry, pigs, cattle, pigeons and ducks. However, all the human studies were hospital-based, with the beta-lactamases reported from clinical samples collected within the hospitals in Nigeria. For the environmental studies, samples were collected from the beach, river, wastewater, and sources of drinking water.

The majority of the studies were carried out in South West Nigeria $(n=36)$, while the rest were carried out in the other regions including South East $(n=7)$, North Central $(n=6)$, North East $(n=3)$, North West $(n=1)$ and South South $(n=2)$. Sixteen $(n=16)$ studies used the broth microdilution method to determine the minimum inhibitory concentrations; other methods used for minimum inhibitory concentrations determination included E-test $(n=3)$ and Vitek-2 $(n=2)$. However, the disc diffusion method $(n=36)$ was mainly used for the antimicrobial susceptibility of bacteria. Forty-three of the 57 studies reported the use of phenotypic screening methods for beta-lactamase production; this included a modified Hodge test and Carba test $(n=6)$ for carbapenemases production as well as the double-disc synergy test $(n=37)$ for other beta-lactamase production. Five different genotypic methods including polymerase chain reaction (PCR), gene sequencing, whole genome sequencing (WGS), isoelectric point and restriction fragment length polymorphism (RFLP) were reported by the studies. Forty-four studies used PCR alone $(n=44)$, eight studies used PCR and gene sequencing, two used PCR with an isoelectric point, one used PCR and whole-genome sequencing, one used PCR with RFLP while only one study used whole-genome sequencing alone for the genotypic detection of various beta-lactamase resistance genes. Among the 57 studies reviewed, the majority of betalactamases were detected in Enterobacteriaceae $(n=54)$, followed by Acinetobacter baumannii $(n=2)$ and Vibrio spp $(n=1)$.
TABLE 1: Distribution of beta-lactamase resistance genes between animals, humans and environmental settings in Nigeria (1900-2019).

\begin{tabular}{|c|c|c|c|c|c|}
\hline $\begin{array}{l}\text { Beta-lactamase } \\
\text { type }\end{array}$ & Gene & Animals & Humans & Environment & Reference \\
\hline \multirow{8}{*}{$\begin{array}{l}\text { AmpC } \\
\text { beta-lactamases }\end{array}$} & $b / a_{\mathrm{ampc}}$ & $1 \dagger$ & 5 & 1 & \multirow{8}{*}{$\begin{array}{l}10,11,12,13,14 \\
15,16,17,18,19 \\
20,21,22,23,24\end{array}$} \\
\hline & $b / a_{\mathrm{CMY}-2}$ & 1 & - & - & \\
\hline & bla ${ }_{\mathrm{CMY}}$ like & 1 & 1 & 1 & \\
\hline & $b / a_{\text {ACT-5 }}$ & 1 & - & - & \\
\hline & $b / a_{\mathrm{ACC}}$ & 1 & - & - & \\
\hline & $b / a_{\mathrm{FOX}-1}$ & 2 & - & - & \\
\hline & $b l a_{\mathrm{DHA}-1}$ & 1 & 1 & - & \\
\hline & $b l a_{\mathrm{ECB}}$ & 1 & - & - & \\
\hline \multirow{14}{*}{$\begin{array}{l}\text { Extended- } \\
\text { spectrum } \\
\text { beta-lactamases }\end{array}$} & $b / a_{c t x m}$ like & 3 & 12 & 1 & \multirow{14}{*}{$\begin{array}{l}10,11,12,13,14,15, \\
17,19,20,23,24,25 \\
26,27,28,29,30,31,32 \\
33,34,35,36,37,38, \\
39,40,41,42,43,44,45 \\
46,47,48,49,50,51,52 \\
53,54,55,56\end{array}$} \\
\hline & $b / a_{c t \times m-1}$ & 2 & 2 & - & \\
\hline & $b l a_{\mathrm{ctxm}-2}$ & - & 1 & - & \\
\hline & $b / a_{\mathrm{ctxm}-14}$ & 1 & 1 & - & \\
\hline & $b / a_{\mathrm{ctxm}-15}$ & 6 & 14 & 2 & \\
\hline & $b / a_{\text {ctxm-27 }}$ & 1 & - & - & \\
\hline & $b l a_{\mathrm{CTX}-\mathrm{M}-55}$ & 1 & - & - & \\
\hline & $b / a_{\mathrm{SHV}-2}$ & - & 1 & 1 & \\
\hline & $b / a_{\text {SHV }-12}$ & - & 2 & 1 & \\
\hline & $b / a_{\mathrm{SHV}-28}$ & - & 1 & - & \\
\hline & $b / a_{\text {SHV-112 }}$ & - & 1 & - & \\
\hline & $b / a_{\mathrm{OXA}-10}$ & - & 1 & - & \\
\hline & $b / a_{\text {VEB-1 }}$ & 1 & 1 & - & \\
\hline & $b / a_{\mathrm{GES}}$ & 1 & 1 & - & \\
\hline \multirow{7}{*}{$\begin{array}{l}\text { Narrow-spectrum } \\
\text { beta-lactamases }\end{array}$} & $b l a_{\mathrm{OXA}-1}$ & 2 & 4 & - & \multirow{7}{*}{$\begin{array}{l}13,14,15,16,19,24,32 \\
35,37,43,57,58,59\end{array}$} \\
\hline & $b / a_{\mathrm{OXA}-2}$ & 1 & 1 & - & \\
\hline & $b l a_{\mathrm{SHV}-1}$ & - & 2 & 1 & \\
\hline & $b l a_{\mathrm{SHV}-11}$ & - & 2 & 1 & \\
\hline & $b l a_{\text {TEM }-1}$ & 3 & 6 & 1 & \\
\hline & $b l a_{\mathrm{TEM}-2}$ & - & 1 & - & \\
\hline & $b l a_{z}$ & - & - & 1 & \\
\hline \multirow[t]{9}{*}{ Carbapenemases } & $b l a_{\mathrm{KPC}}$ & - & 1 & - & \multirow{9}{*}{$\begin{array}{l}19,22,59,60,61 \\
62,63,64,65,66\end{array}$} \\
\hline & $b / a_{\mathrm{OXA}-23}$ & - & 1 & - & \\
\hline & $b / a_{\mathrm{OXA}-48}$ & - & 1 & - & \\
\hline & $b / a_{\mathrm{OXA}-181}$ & - & 3 & - & \\
\hline & $b / a_{\mathrm{NDM}-1}$ & - & 5 & 1 & \\
\hline & $b / a_{\mathrm{NDM}-5}$ & - & 1 & - & \\
\hline & $b / a_{\mathrm{VIM}-1}$ & - & 5 & - & \\
\hline & $b / a_{\mathrm{VIM}-2}$ & - & 1 & - & \\
\hline & $b / a_{\mathrm{VIM}-5}$ & - & & 1 & \\
\hline
\end{tabular}

Note: The values in each cell represent the number of articles reporting the beta-lactamase genes.

\section{One Health distribution of beta-lactamase resistance genes in Nigeria}

Thirty-six different beta-lactamase genes were detected and reported in the 57 studies (Table 1). Seventeen genes were detected in animals, 28 in humans, and 12 in the environment. These genes belong to the AmpC, 10,11,12,13,14,15,16,17,18,19,20,21,22,23,24 extended-spectrum, $10,11,12,13,14,15,17,19,20,23,24,25,26,27,28,29,30,31,32,33,34,35,36,37,3$ $8,39,40,41,42,43,44,45,46,47,48,49,50,51,52,53,54,55,56$ narrow-spectrum, $13,14,15,16,19,24$, $32,35,37,43,57,58,59$ and carbapenemase beta-lactamase resistance genes. ${ }^{19,22,59,60,61,62,63,64,65,66}$ Eight genes $\left(b l a_{\text {CTX-M-1 }{ }^{\prime}} b l a_{\text {СТX-M-1 } 4^{\prime}} b l a_{\mathrm{DHA}^{\prime}}\right.$ $b l a_{\mathrm{GES}-1}, b l a_{\mathrm{OXA}-1,}, b l a_{\mathrm{OXA}-2,} b l a_{\mathrm{TEM}-1}$ and $\left.b l a_{\mathrm{VEB}-1}\right)$ were found in animals and humans; five genes $\left(b l a_{\mathrm{NDM}-1,}, b l a_{\mathrm{SHV}-1,} b l a_{\mathrm{SHV}-2,}\right.$ $b l a_{\mathrm{SHV}-11}$, and $\left.b l a_{\mathrm{SHV}-12}\right)$ were common to both humans and the environment while none of the genes was unique to both animals and the environment (Table 1). Four genes, namely $b l a_{\mathrm{AmpC}^{\prime}} b l a_{\mathrm{CMY}}, b l a_{\mathrm{TEM}-1}$ and the international pandemic $b l a_{\mathrm{CTX}-\mathrm{M}-15}$, were reportedly detected from animals, humans and the environment. No carbapenemase gene was reported 
in animals but seven beta-lactamase genes $\left(b l a_{\mathrm{ACC}}, b l a_{\mathrm{ACT}-5}\right.$, $b l a_{\mathrm{CMY}-2^{\prime}} b l a_{\mathrm{CTX}-\mathrm{M}-27^{\prime}} b l a_{\mathrm{CTX}-\mathrm{M}-55^{\prime}}, b l a_{\mathrm{ECB}}$, and $\left.b l a_{\mathrm{FOX}-1}\right)$ were unique to animals alone, 12 (bla $a_{\mathrm{CTX}-\mathrm{M}-2}, b l a_{\mathrm{KPC}}, b l a_{\mathrm{NDM}-5^{2}}, b l a_{\mathrm{OXA}-10^{\prime}} b l a_{\mathrm{OXA}-23^{\prime}}$ $b l a_{\mathrm{OXA}-48^{\prime}} b l a_{\mathrm{OXA}-181^{\prime}}, b l a_{\mathrm{SHV}-28^{\prime}}, b l a_{\mathrm{SHV}-112^{\prime}}, b l a_{\mathrm{TEM}-2^{\prime}} b l a_{\mathrm{VIM}-1^{\prime}}$, and $\left.b l a_{\mathrm{VIM}-2}\right)$ were unique to humans, while only two genes $\left(b l a_{\mathrm{VIM}-5}\right.$ and $b l a_{\mathrm{z}}$ ) were unique to the environment.

\section{Proportion estimates of extended-spectrum beta-lactamase genes in Nigeria}

Thirty-two studies were included in the meta-analysis for the generation of the overall pooled estimate of ESBL. The overall pooled proportion of ESBL was 31\% (95\% CI: $26 \%-$ $36 \%, p<0.001)$. The overall between-study heterogeneity was significant and substantial $\left(I^{2}=97.87 \%, p<0.001\right)$. Between the studies, the proportions of ESBL genes range from $1 \%$ to $95 \%$ (Figure 2). The overall proportion estimate of ESBLs in human-based studies was 35\% (95\% CI: $27 \%-43 \%$, $p<0.001)$, in animal studies was 25\% (95\% CI: 17\% - 33\%, $p<$ $0.001)$ and in environmental-based studies was $22 \%$ (95\% CI: $0 \%-44 \%, p=0.06)$. A separate meta-analysis was conducted to determine the proportion estimate of $b l a_{\mathrm{CTX}-\mathrm{M}-15}$ producing Enterobacteriaceae in Nigeria (Figure 3); 17 studies were included in the quantitative analysis. The overall pooled proportion was $46 \%$ (95\% CI: 36\% - 57\%), the unexplained between-study heterogeneity was significant and substantial $\left(I^{2}=99.04 \%, p<0.001\right)$. The proportion estimate of $b l a_{\text {CTX-M-15 }}$ gene from human-based studies was 47\% (95\% CI: $25 \%-$ $69 \%$ ), for the animal studies it was $47 \%$ (95\% CI: $27 \%-67 \%$ ) and for the environmental-based studies, it was $41 \%(95 \%$ CI: $33 \%-50 \%)$. Between subgroups, heterogeneity was non-significant $(p=0.812)$. However, the within-group heterogeneity for both human and animal studies was significant and substantial $\left(I^{2}=99 \%, p<0.001\right)$.

\section{Proportion estimates of $\mathrm{AmpC}$ and carbapenemase beta-lactamase genes in Nigeria}

Based on 13 studies, the overall pooled proportion of AmpC beta-lactamases was 32\% (95\% CI: $11 \%-52 \%, p<0.001)$, with the overall between-study heterogeneity significant and substantial ( $\left.I^{2} 99.15 \%, p<0.001\right)$. However, the proportions of AmpC beta-lactamases reported from the studies range from $2 \%$ to $88 \%$ (Figure 4). The proportion of AmpC betalactamases was higher in humans at 37\% (95\% CI: $4 \%-70 \%$, $p=0.03)$ than in the environment at 20\% (95\% CI: $14 \%-25 \%$, $p<0.001)$ and animals at $26 \%$ (95\% CI: $0 \%-64 \%, p=0.20)$.

Six studies were included in the carbapenemase pooled proportion estimation (Figure 5). The overall pooled proportion of carbapenemases was $8 \%$ (95\% CI: $5 \%-12 \%, p<$ 0.001). Between the studies, the proportions of carbapenemase beta-lactamases ranged from $1 \%$ to $48 \%$, while the overall between-study heterogeneity was significant $\left(I^{2}=87.6 \%, p<\right.$ $0.001)$. The proportion of carbapenemases for the environment was $15 \%$ (95\% CI: $8 \%-22 \%, p<0.001)$ and was higher than that observed in human studies (6\%; 95\% CI: 3\% - 10\%, $p<$ $0.001)$. Between-study heterogeneity was mostly due to studies from human setting.

\section{Discussion}

In Africa, data on AMR are often limited due to the lack of sustainableintegrated national AMRsurveillance programmes. The lack of systematically collected data has impeded the proper understanding of resistance to critically important antimicrobials such as beta-lactam drugs in Africa compared to the high-income countries. This study identified the different types, distribution and proportion estimates of beta-lactamase resistance genes in Nigeria contributing to the national, continental and global molecular epidemiology of beta-lactamases. It provides data that can support ongoing efforts of integrative surveillance programmes and policies for the mitigation of AMR within Nigeria. From this review, beta-lactamases were mainly detected in the Enterobacteriaceae bacteria family. This higher detection in Enterobacteriaceae may be skewed because the studies included in this review targeted this bacterial family. Also, bacteria of the Enterobacteriaceae family are ubiquitous in nature, causing different infections (particularly Escherichia coli) in both humans and animals and can readily be maintained in the environment. Also, the emergence and occurrences of AMR due to beta-lactamases in Enterobacteriaceae are driven mainly by ease of acquisition of AMR genes and the rapid dissemination of resistance determinants by Enterobacteriaceae to other pathogenic and non-pathogenic bacteria., 2,67

Among the 57 studies, 75\% reported a double-disc synergy test for the phenotypic detection of beta-lactamases before the genotypic method. This complies with the Clinical Laboratory Standard Institute guideline for the screening and detection of beta-lactamases in bacteria. The PCR method was mostly reported; this may be due to ease of access and reduced cost compared with other advanced techniques such as WGS. ${ }^{68}$ While the WGS method is commonly used in high income countries for research and surveillance programmes, the use of WGS in beta-lactamase studies in Nigeria is still limited. Only two studies reported the use of WGS for the detection of beta-lactamase genes. This may be due to the limited access to the necessary equipment, expertise, and bioinformatics skill in Nigeria.

The majority of the articles published were from southern Nigeria and from human health studies. Therefore, betalactamases reported in this systematic review may not reflect the true geographic distribution of beta-lactamases genes in Nigeria. However, beta-lactamases were detected more in isolates from human settings, consistent with what has been reported from a similar South African review. ${ }^{68}$

In this review, 36 different types of beta-lactamases had been detected and reported in Nigeria. These beta-lactamases included the clinically important types such as ESBLs, AmpC, and carbapenemases that are commonly responsible for treatment failures in both human and veterinary settings. ${ }^{69,70}$ While previous reviews within Africa focused mainly on systematic reviews of ESBL in Enterobacteriaceae, ${ }^{71,72,73}$ this 


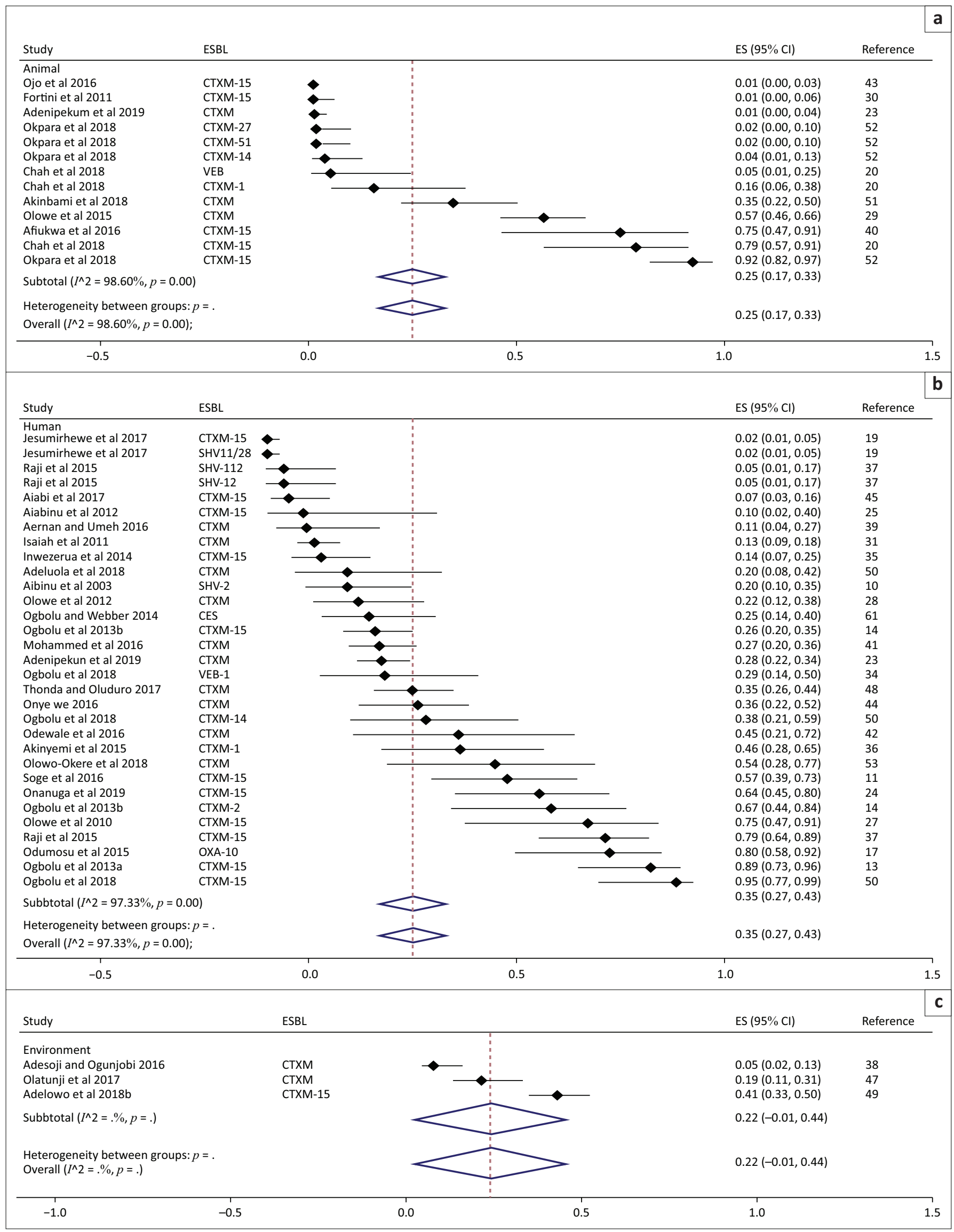

$P$-values generated using STATA SE version 15.0 and does not represent exact values.

$\mathrm{Cl}$, confidence interval; ESBL, extended-spectrum beta-lactamases.

FIGURE 2: Subgroup analysis and forest plot of proportion estimates of extended-spectrum beta-lactamases for animal (a), human (b) and environmental settings (c) in Nigeria (1990-2019). 


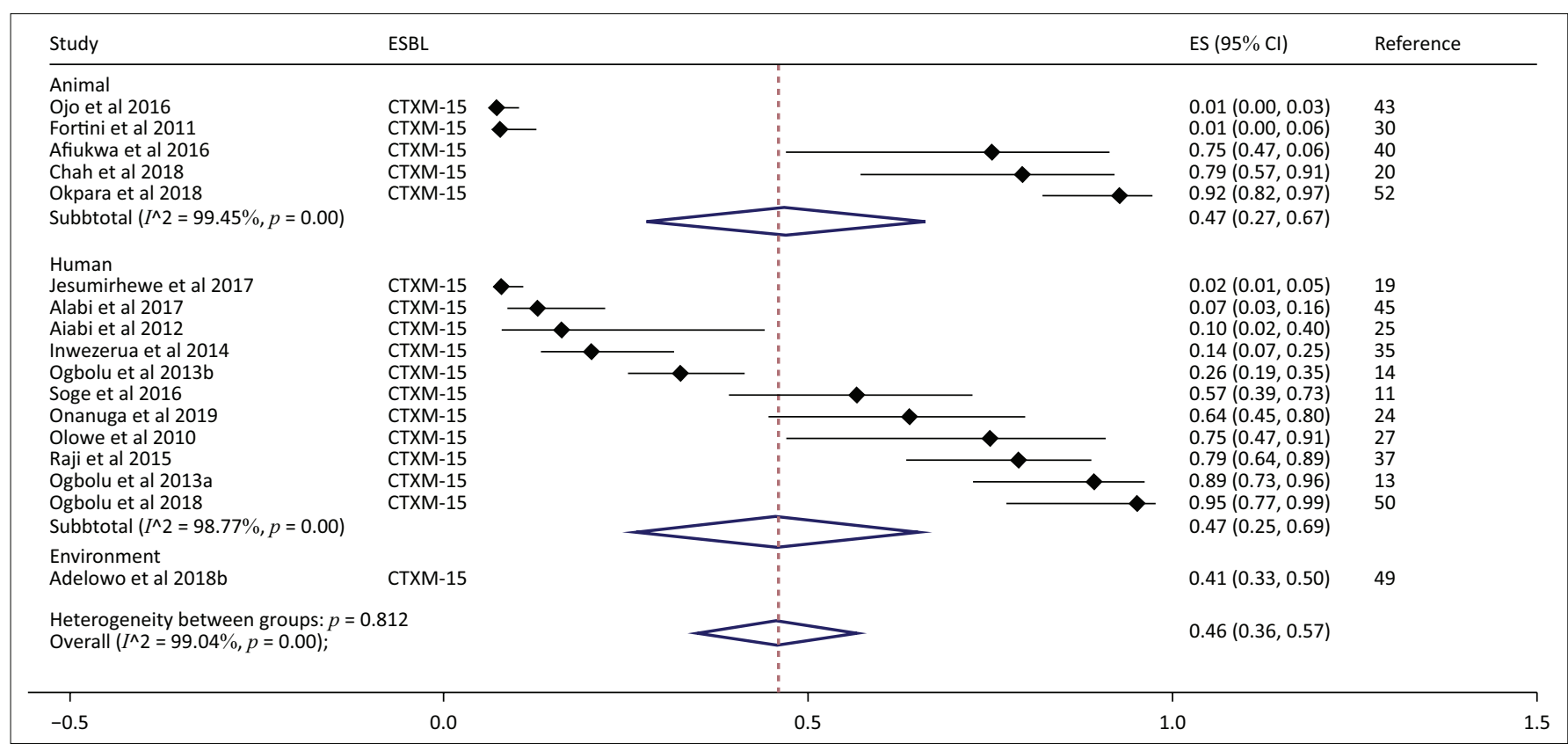

Note: Midpoint of each horizontal line segment shows the proportion estimate of extended-spectrum beta-lactamases resistance genes in each study. Diamond sign represents the pooled proportion from all studies included in the random-effect meta-analysis. $P$-values generated using STATA SE version 15.0 and does not represent exact values.

$\mathrm{Cl}$, confidence interval; ESBL, extended-spectrum beta-lactamases.

FIGURE 3: Subgroup analysis and forest plot of proportion estimates of bla $a_{\text {CTX-M-15 }}$ extended-spectrum beta-lactamase in Nigeria (1990-2019).

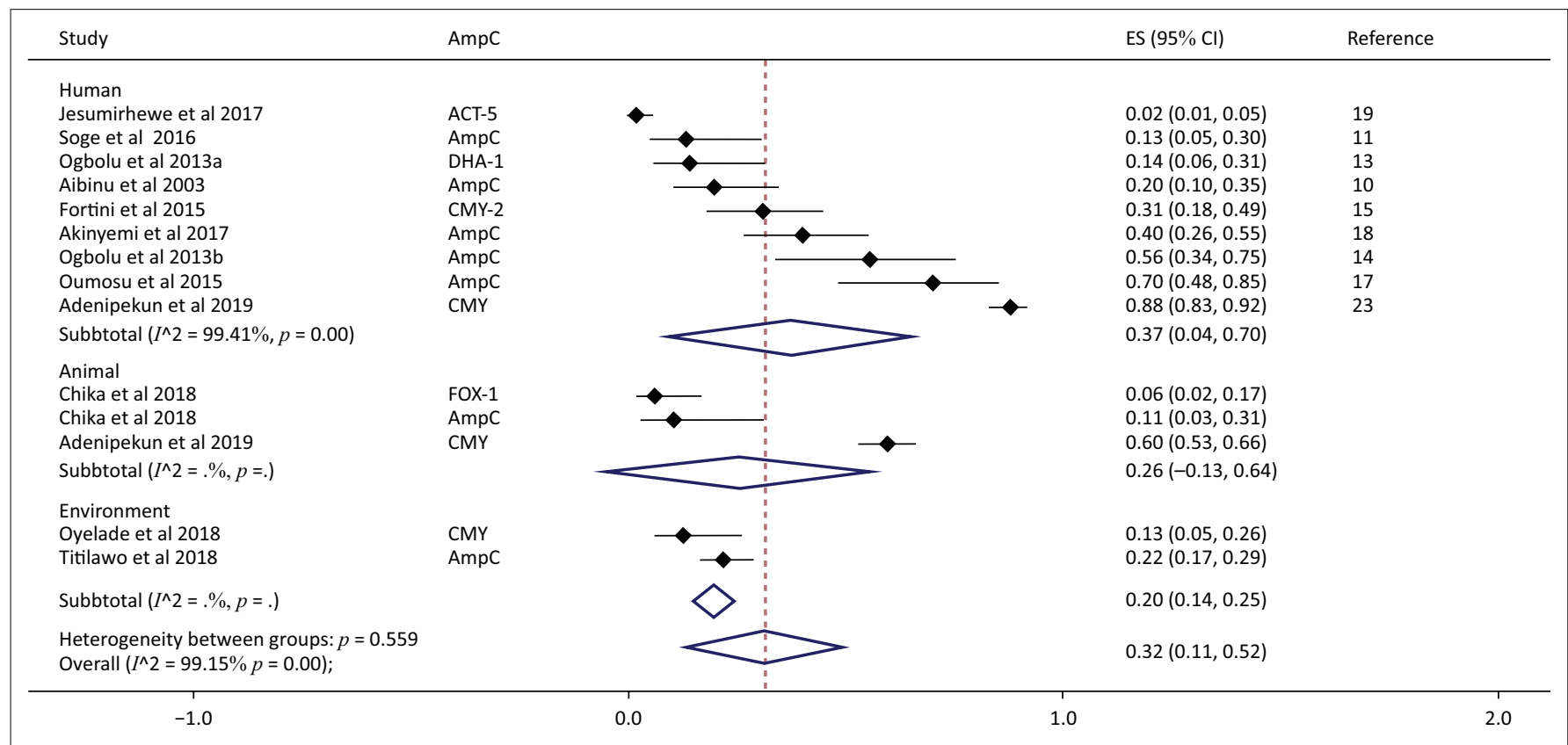

Note: Midpoint of each horizontal line segment shows the proportion estimate of bla $a_{\text {cTx-1.1 }}$ resistance gene in each study. Diamond sign represents the pooled proportion from all studies included in the random-effect meta-analysis. $P$-values generated using STATA SE version 15.0 and does not represent exact values.

$\mathrm{Cl}$, confidence interval.

FIGURE 4: Subgroup analysis and forest plot of proportion estimates of AmpC beta-lactamases for human, animal and environmental settings in Nigeria (1990-2019).

study was conducted to capture as many beta-lactamases detected in Nigeria as possible beyond ESBLs. This is because ESBLs, the AmpC-type, and the carbapenemases remain the most clinically challenging beta-lactamase resistance gene family in both human and animal health. Antibiotic resistance is recognised as a One health challenge because of the dissemination of important resistant bacteria and genes among humans, animals and the environment at a global scale. ${ }^{74}$ This review showed that of the 36 betalactamases reported in Nigeria, some of the genes detected in
Nigeria were reported from more than one setting. Between human and environmental sources, five different betalactamases were reported while between animal and human sources, eight different genes were reported. This finding further highlights a One health AMR transmission. Also, it reveals how the environment, including food-animal production systems, could serve as reservoirs of essential AMR genes, driving transmission and colonisation as well as infection of clinically important beta-lactamase producing bacteria in humans. ${ }^{6}$ 


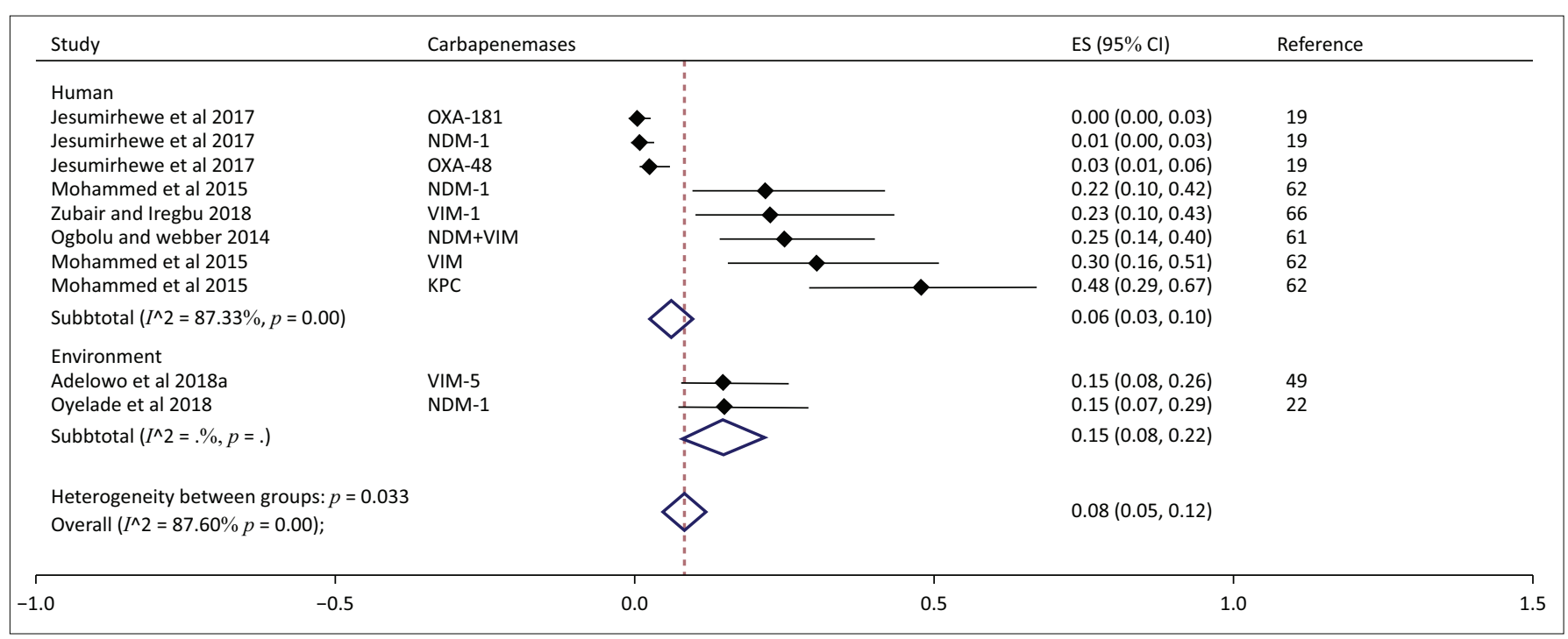

Note: Midpoint of each horizontal line segment shows the proportion estimate of carbapenemase resistance genes in each study. Diamond sign represents the pooled proportion from all studies included in the random-effect meta-analysis. $P$-values generated using STATA SE version 15.0 and does not represent exact values.

$\mathrm{Cl}$, confidence interval.

FIGURE 5: Subgroup analysis and forest plot of proportion estimates of carbapenemase beta-lactamases for human and environmental settings in Nigeria (1990-2019).

Epidemiologically, all the beta-lactamases detected in Nigeria have been reported from other parts of the world. Five different types of the AmpC beta-lactamase group (bla ${ }_{\mathrm{ACC}}$ $b l a_{\mathrm{ACT}}, b l a_{\mathrm{CMY}-2}, b l a_{\mathrm{DHA},}$ and $\left.b l a_{\mathrm{FOX}-1}\right)$ were reported in Nigeria to date based on this review. While $b l a_{\mathrm{CMY}-2}$ is the most important AmpC-type and has the broadest geographic spread, based on this review this gene was not common in Nigeria compared to other countries such as the United States and Canada. ${ }^{8}$ Within Africa, there are limited reports on AmpC beta-lactamases. However, $b l a_{\mathrm{CMY}-2}$ and $b l a_{\mathrm{DHA}}$ have been reported in Algeria, ${ }^{71}$ while $b l a_{\mathrm{ACC}}, b l a_{\mathrm{DHA}^{\prime}}$ and $b l a_{\mathrm{FOX}-1}$ were reported in Uganda. ${ }^{75}$ No carbapenemase gene was reported in animals in Nigeria based on this review; however, carbapenemases have been commonly reported from wildlife, food-producing animals and companion animals from other countries. ${ }^{70,76}$ The lack of reports of carbapenemase from animal settings may be due to the lack of research or surveillance in this regard and not necessarily the absence of carbapenemase genes in animals from Nigeria. All the epidemiologically important carbapenemases including $b l a_{\mathrm{KPC}}, b l a_{\mathrm{NDM}-1}, b l a_{\mathrm{OXA}-23}, b l a_{\mathrm{OXA}-48}, b l a_{\mathrm{OXA}-181^{\prime}}, b l a_{\mathrm{VIM}-1}, b l a_{\mathrm{VIM}-2}$ and $b l a_{\mathrm{VIM}-5}$ reported in Nigeria were mostly from the human setting. These carbapenemases have been reported in many African countries including South Africa, Gabon, Angola, Senegal, Kenya, Tanzania, Morocco, Algeria, Tunisia, Libya and Egypt. ${ }^{77,78}$ In most cases, $b l a_{\mathrm{NDM}-1}$ and $b l a_{\mathrm{OXA}-48}$ are the commonly reported carbapenemases. These carbapenemases are known to be prevalent in South Asian countries, particularly the Indian sub-continent; the trend in Africa may indicate that the global dissemination of carbapenemaseproducing Enterobacteriaceae has reached the African continent.

Among the ESBLs, five different groups were reported including $b l a_{\mathrm{CTX}-\mathrm{M}^{\prime}} b l a_{\mathrm{GES},} b l a_{\mathrm{OXX}^{\prime}} b l a_{\mathrm{SHV}}$ and $b l a_{\mathrm{VEB}}$ with $b l a_{\mathrm{CTX}-\mathrm{M}}$ the most commonly reported. During the last decade, $b l a_{\text {СТX-M }}$-type enzymes have spread globally, becoming the most common ESBL in Enterobacteriaceae from both humans and animals. ${ }^{79,80}$ Among the different types of $b l a_{\text {СТХ-M }}$ reported in Nigeria, $b l a_{\text {CTX-M-1, }} b l a_{\text {CTX-M-2, }} b l a_{\text {CTX-M- } 14}$ and $b l a_{\text {CTХ-M- } 55}$ are known to be commonly detected in food animals. ${ }^{4,8}$ However, the internationally disseminated $b l a_{\text {CTX-M-15 }}$ has been associated with the E. coli serotype O25:H4 (ST131), causing both community and hospital-acquired human infections. ${ }^{79,81}$ bla $_{\text {СТХ-M-15 }}$ was also the only ESBL commonly reported in human, animal and environmental settings in this review. This revealed that $b l a_{\mathrm{CTX-M-15}}$ is ubiquitous and prevalent in all environments with possible anthropozoonotic and zooanthroponotic transmissions. $b l a_{\mathrm{CTX-M-15}}$ has also been commonly reported from other regions of Africa, ${ }^{71}$ which may suggest $b l a_{\text {CTX-M-15 }}$ is a predominant ESBL in Africa similar to what has been reported in the United States, Europe and Asia. ${ }^{82}$ bla $_{\mathrm{SHV}}$ ESBLs, in particular, $b l a_{\mathrm{SHV}-12}$ and $b l a_{\mathrm{SHV}-2}$, reported in Nigeria have also been frequently detected in Europe and North America. ${ }^{83}$ However, the globally disseminated $b l a_{\mathrm{TEM}}$ ESBLs, that is, $b l a_{\mathrm{TEM}-10}$ and $b l a_{\mathrm{TEM}-52^{\prime}}$ were not reported in Nigeria; narrow-spectrum $b l a_{\text {TEM-1 }}$ coding for ampicillin resistance was common.

From the meta-analysis, subgroup analyses provide some explanation for the between-study heterogeneity and also the pooled proportion of ESBLs based on the one health distribution. The proportion estimate of ESBLs in Nigeria was $32.00 \%$ compared to $2.03 \%$ of AmpC and $8.00 \%$ of carbapenemases. This is unsurprising: even though AmpC has been found worldwide and carbapenemases are increasingly being reported, both AmpC and carbapenemases are less prevalent than ESBL globally, ${ }^{5}$ and this is consistent with the finding of this review. The proportion estimate of $29.00 \%$ for AmpC in the human setting in this review is slightly higher than the $28.30 \%$ estimate from Egypt, ${ }^{84}$ but lower than $34.00 \%$ from Canada ${ }^{85}$ and $39.60 \%$ from Uganda. ${ }^{75}$ The proportion estimate of $8.00 \%$ for carbapenemases is comparable to what has been reported from other African countries. ${ }^{77}$ The lower proportion of carbapenemases reported in Nigeria is 
encouraging considering the importance of carbapenems as last resort antimicrobials for treating cases of ESBL-producing bacterial infections. While carbapenems resistance is emerging globally at a rapid rate, surveillance and prudent use practices of carbapenems will monitor and minimise multidrug resistant bacterial infections at the national level. The proportion estimate of $32.00 \%$ for ESBL in human, animal and environmental settings from this review is higher than the $22.60 \%$ reported by a similar study from Tanzania. ${ }^{73}$ The proportion estimate of $35.00 \%$ for ESBLs in the human setting is comparable to proportions previously reported for different countries within Africa. ${ }^{72,71}$ For $b l a_{\mathrm{CTX}_{\mathrm{M}}{ }^{\prime}}$ the proportion estimate of $34.00 \%$ for the $b l a_{\text {СтХ-м }}$ gene in Nigeria was lower compared to $56.70 \%$ reported in $\operatorname{Iran}^{86}$ and $69.00 \%$ from a previous similar systematic review. ${ }^{87}$ However, the proportion estimate of $45.00 \%$ for $b l a_{\text {CTX-M-15 }}$ in Nigeria was lower than $78.00 \%$ reported from both Tanzania ${ }^{73}$ and Sudan. ${ }^{88}$

None of the articles reviewed reported any risk factors associated with the occurrence of beta-lactamase resistance genes in Nigeria; however, the occurrences and proportion estimates of clinically significant beta-lactamases reported maybe due to the uncontrolled and indiscriminate use of antimicrobials as well as the lack of active infection control programmes in most animal and human settings. In Nigeria, animal and human antimicrobials can readily be purchased from both pharmaceutical and non-pharmaceutical stores without prescriptions. ${ }^{89}$ This is a cause for concern because indiscriminate use of antimicrobials drives resistance; also, poor hygienic practices in both community and hospital environments facilitates the spread and transmission of important multidrug resistant bacteria. In addition, extendedspectrum cephalosporins and carbapenems have been designated as critically important antimicrobials by the World Health Organization with limited alternatives in the case of treatment failure. ${ }^{1}$ Lastly, infections with bacteria producing ESBL or AmpC or carbapenemase may result in prolonged hospitalisation, higher treatment costs, delays in the initiation of timely and adequate antimicrobial therapy, and increased risk of morbidity and mortality. ${ }^{7}$ Therefore, resistance to clinically important beta-lactamases is a significant threat to public health and collaborative efforts.

\section{Limitations}

This review is not without limitations. The literature search was limited to the PubMed ${ }^{\circledR}$, Google Scholar and AJOL electronic databases; therefore, some studies may have been omitted in this review. Also, information on risk factors associated with beta-lactamase resistance was not available. This information is necessary for better explanation of the beta-lactam resistance observed in Nigeria and a better understanding of the epidemiology of beta-lactamase resistance genes in Nigeria.

\section{Conclusion}

This review has provided information on the beta-lactamases distribution in Nigeria. Thirty-six different beta-lactamases have been reported in Nigeria with $b l a_{\text {CTX-M-15 }}$ commonly distributed in animals, humans and the environment consistent with the reports from other African countries. Carbapenemases are most common in human settings and have not been reported in animals yet. The information provided on beta-lactamase resistance genes is necessary for better understanding of the national and global molecular epidemiology of clinically important beta-lactamase genes, especially AmpC, ESBLs and carbapenemases.

\section{Acknowledgements Competing interests}

The authors declare that they have no financial or personal relationships that may have inappropriately influenced them in writing this article.

\section{Authors' contributions}

B.B.A., M.A., O.A., O.K. and E.O. conceptualised the research and equally carried out the research and the writing of the manuscript.

\section{Sources of support}

This research received no specific grant from any funding agency in the public, commercial or not-for-profit sectors.

\section{Data availability}

Data sharing is not applicable to this article as no new data were created or analysed in this study.

\section{Disclaimer}

The views and opinions expressed in this article are those of the authors and do not necessarily reflect the official policy of any affiliated agency of the authors.

\section{References}

1. World Health Organization. Critically important antimicrobials for human medicine: Ranking of antimicrobial agents for risk management of antimicrobial
resistance due to non-human use [homepage on the Internet]. Vol. 5th rev. Geneva; 2017 [cited 2019 Feb 5]. Available from: http://apps.who.int/iris/bitstre am/10665/255027/1/9789241512220-eng.pdf

2. Smet A, Martel A, Persoons D, et al. Broad-spectrum $\beta$-lactamases among Enterobacteriaceae of animal origin: Molecular aspects, mobility and impact on public health. FEMS Microbiol Rev. 2010;34(3):295-316. https://doi.org/10.1111/ j.1574-6976.2009.00198.x

3. Bradford PA. Extended-spectrum $\beta$-lactamases in the 21st century: Characterization, epidemiology, and detection of this important resistance threat. Clin Microbiol Rev. 2001;14(4):933-951. https://doi.org/10.1128/CMR.14.4.933951.2001

4. Seiffert SN, Hilty M, Perreten V, Endimiani A. Extended-spectrum cephalosporinresistant gram-negative organisms in livestock: An emerging problem for human health? Drug Resist Updat. 2013;16(1-2):22-45. https://doi.org/10.1016/j. drup.2012.12.001

5. Pfeifer $Y$, Cullik A, Witte W. Resistance to cephalosporins and carbapenems in Gram-negative bacterial pathogens. Int J Med Microbiol. 2010;300(6):371-379. https://doi.org/10.1016/j.ijmm.2010.04.005

6. Rousham EK, Unicomb L, Islam MA. Human, animal and environmental contributors to antibiotic resistance in low-resource settings: Integrating behavioural, epidemiological and one health approaches. Proc Roy Soc B: Biol Sci. 2018;285(1876):20180332. https://doi.org/10.1098/rspb.2018.0332

7. Pitout JD, Laupland KB. Extended-spectrum $\beta$-lactamase-producing Enterobacteriaceae: An emerging public-health concern. Lancet Infect Dis. 2008;8(3):159-166. https://doi.org/10.1016/S1473-3099(08)70041-0 
8. EFSA Panel on Biological Hazards (BIOHAZ). Scientific opinion on the public health risks of bacterial strains producing extended-spectrum $\beta$-lactamases and/or AmpC $\beta$-lactamases in food and food-producing animals: ESBL/AmpC in foodproducing animals and foods. EFSA J. 2011;9(8):2322. https://doi.org/10.2903/j. producing anim

9. Moher D, Liberati A, Tetzlaff J, Altman DG, PRISMA Group. Preferred reporting items for systematic reviews and meta-analyses: The PRISMA statement. PLOS Med. 2009;6(7):e1000097. https://doi.org/10.1371/journal.pmed.1000097

10. Aibinu IE, Ohaegbulam VC, Adenipekun EA, Ogunsola FT, Odugbemi TO, Mee BJ. Extended-spectrum $\beta$-lactamase enzymes in clinical isolates of Enterobacter species from Lagos, Nigeria. J Clin Microbiol. 2003;41(5):2197-2200. https://doi. org/10.1128/JCM.41.5.2197-2200.2003

11. Soge OO, Queenan AM, Ojo KK, Adeniyi BA, Roberts MC. CTX-M-15 extendedspectrum $\beta$-lactamase from Nigerian Klebsiella pneumoniae. J Antimicrob Chemother. 2006;57(1):24-30. https://doi.org/10.1093/jac/dki429

12. Ogunleye AO, Carlson SA. Survey of 3rd generation cephalosporin genes in multiresistant Salmonella serotypes from septic poultry and an asymptomatic healthy pig from Nigeria. Afr J Microb Res. 2011;5(15):2139-2144. https://doi.org/ 10.5897/AJMR11.340

13. Ogbolu DO, Alli OAT, Olanipekun LB, Ojo OI, Makinde OO. Faecal carriage of extended-spectrum beta-lactamase (ESBL)-producing commensal Klebsiella pneumoniae and Escherichia coli from hospital out-patients in Southern Nigeria. Int J Medical Sci. 2013;5(3):97-105.

14. Ogbolu DO, Daini OA, Ogunledun A, Terry Alli OA, Webber MA. Dissemination of IncF plasmids carrying beta-lactamase genes in Gram-negative bacteria from Nigerian hospitals. J Infect Dev Ctries. 2013;7(05):382-390. https://doi.org/ 10.3855/jidc.2613

15. Fortini D, Fashae K, Villa L, Feudi C, García-Fernández A, Carattoli A. A nove plasmid carrying blaCTX-M-15 identified in commensal Escherichia coli from healthy pregnant women in Ibadan, Nigeria. J Glob Antimicrob Resist. 2015;3(1):9-12. https://doi.org/10.1016/j.jgar.2014.12.002

16. Titilawo Y, Obi L, Okoh A. Antimicrobial resistance determinants of Escherichia coli isolates recovered from some rivers in Osun State, South-Western Nigeria: Implications for public health. Sci Total Environ. 2015;523:82-94. https://doi. org/10.1016/j.scitotenv.2015.03.095

17. Odumosu BT, Adeniyi BA, Chandra R. First Detection of OXA-10 extendedspectrum beta-lactamases and the occurrence of $\operatorname{mexR}$ and $n f x B$ in clinical isolates of Pseudomonas aeruginosa from Nigeria. Chemotherapy. 2016;61(2):87-92. of Pseudomonas aeruginosa from
https://doi.org/10.1159/000441712

18. Akinyemi KO, Iwalokun B, Oyefolu A, Fakorede C. Occurrence of extendedspectrum and AmpC beta-lactamases in multiple drug resistant Salmonella isolates from clinical samples in Lagos, Nigeria. Infect Drug Resist. 2017;10:19-25. https://doi.org/10.2147/IDR.S123646

19. Jesumirhewe C, Springer B, Lepuschitz S, Allerberger F, Ruppitsch W. Carbapenemase-producing enterobacteriaceae isolates from Edo State, Nigeria. Antimicrob Agents Chemother. 2017;61(8):3pp. https://doi.org/10.1128/AAC 00255-17

20. Chah KF, Ugwu IC, Okpala A, et al. Detection and molecular characterisation of extended-spectrum $\beta$-lactamase-producing enteric bacteria from pigs and chickens in Nsukka, Nigeria. J Glob Antimicrob Resist. 2018;15:36-40. https://doi. org/10.1016/j.jgar.2018.06.002

21. Chika E, Charles E, Ifeanyichukwu I, Michael A. First detection of FOX-1 AmpC B-lactamase gene expression among Escherichia coli isolated from abattoi samples in Abakaliki, Nigeria. Oman Med J. 2018;33(3):243-249. https://doi. org/10.5001/omj.2018.44

22. Oyelade AA, Adelowo OO, Fagade OE. bla NDM-1 $_{\text {- }}$ producing Vibrio parahaemolyticus and $V$. vulnificus isolated from recreational beaches in Lagos, Nigeria. Environ Sci Pollut Res. 2018;25(33):33538-33547. https://doi.org/10.1007/s11356-0183306-2

23. Adenipekun EO, Jackson CR, Ramadan $\mathrm{H}$, et al. Plasmid replicons and $\beta$-lactamaseencoding genes of multidrug-resistant Escherichia coli isolated from human and food animals in Lagos, Southwest Nigeria. Microb Drug Resist. 2019;25(10): 1410-1423. https://doi.org/10.1089/mdr.2018.0305

24. Onanuga A, Mahindroo J, Singh S, Taneja N. Phenotypic and molecular characterization of antimicrobial resistant Escherichia coli from urinary tract infections in Port-Harcourt, Nigeria. Pan Afr Med J. 2019;34:144. https://doi. org/10.11604/pamj.2019.34.144.18182

25. Aibinu I, Pfeifer Y, Peters F, et al. Emergence of bla ${ }_{\text {CTX-M-15 }}$, qnrB1 and $\operatorname{aac}\left(6^{\prime}\right)-\mathrm{lb}-\mathrm{cr}$ resistance genes in Pantoea agglomerans and Enterobacter cloacae from Nigeria (sub-Saharan Africa). J Med Microbiol. 2012;61(1):165-167. https://doi. org/10.1099/jmm.0.035238-0

26. Kasap M, Fashae K, Torol S, Kolayli F, Budak F, Vahaboglu H. Characterization of ESBL (SHV-12) producing clinical isolate of Enterobacter aerogenes from a tertiary care hospital in Nigeria. Ann Clin Microbiol Antimicrob. 2010;9(1):1. https://doi. org/10.1186/1476-0711-9-1

27. Olowe OA, Grobbel M, Büchter B, Lübke-Becker A, Fruth A, Wieler LH. Detection of bla bx $_{\text {- }}$ extended-spectrum $\beta$-lactamase genes in Escherichia coli from hospital patients in Nigeria. Int J Antimicrob Agents. 2010;35(2):206-207. https:// doi.org/10.1016/j.ijantimicag.2009.10.004

28. Olowe OA, Oladipo GO, Makanjuola OA, Olaitan JO. Antimicrobial susceptibility and occurrence of resistance genes among Salmonella arizonae isolated from chicken meat samples in Sokoto metropoplis Sokoto State, Nigeria. Int J Pharma Med Biol Sci. 2012;1(2):129-138.

29. Olowe OA, Adewumi O, Odewale G, Ojurongbe O, Adefioye OJ. Phenotypic and molecular characterisation of extended-spectrum beta-lactamase producing Escherichia coli obtained from animal fecal samples in Ado Ekiti, Nigeria. J Environ Public Health. 2015;2015:1-7. https://doi.org/10.1155/2015/497980
30. Fortini D, Fashae K, Garcia-Fernandez A, Villa L, Carattoli A. Plasmid-mediated quinolone resistance and $\beta$-lactamases in Escherichia coli from healthy animals from Nigeria. J Antimicrob Chemother. 2011;66(6):1269-1272. https://doi.org/ from Nigeria. J Antimic

31. Isaiah I, Nche B, Nwagu I, Nwagu I. Incidence of temonera, sulphuhydryl variables and cefotaximase genes associated with beta-lactamase producing Escherichia coli in clinical isolates. N Am J Med Sci. 2011;3(12)557-561. https://doi. org/10.4297/najms.2011.3554

32. Iroha IR, Esimone CO, Neumann S, et al. First description of Escherichia coli producing CTX-M-15- extended spectrum beta lactamase (ESBL) in out-patients from south eastern Nigeria. Ann Clin Microbiol Antimicrob. 2012;11(1):19. https://doi.org/10.1186/1476-0711-11-19

33. Akujobi CN, Ezeanya CC. Emergence of carbapenem resistance among extendedspectrum beta-lactamase isolate of Escherichia coli from clinical specimens in a tertiary hospital, Nigeria. Int J Microbiol Res. 2013;5(2):367-370. https://doi. org/10.9735/0975-5276.5.2.367-370

34. Ogbolu DO, Terry Alli OA, Webber MA, Oluremi AS, Oloyede OM. CTX-M-15 is established in most multidrug-resistant uropathogenic Enterobacteriaceae and Pseudomonaceae from hospitals in Nigeria. Europe J Microbiol Immunol. 2018;8(1):20-24. https://doi.org/10.1556/1886.2017.00012

35. Inwezerua C, Mendonça N, Calhau V, Domingues S, Adeleke OE, Da Silva GJ. Occurrence of extended-spectrum beta-lactamases in human and bovine isolates of Escherichia coli from Oyo state, Nigeria. J Infect Dev Ctries. 2014;8(06):774779. https://doi.org/10.3855/jidc.3430

36. Akinyemi KO, Iwalokun B, Alafe O, Mudashiru S, Fakorede C. bla CTX-M-I $_{\text {group }}$ extended spectrum beta lactamase-producing Salmonella typhi from hospitalize patients in Lagos, Nigeria. Infect Drug Resist. 2015(8);99-106. https://doi. org/10.2147/IDR.S78876

37. Raji MA, Jamal W, Ojemeh O, Rotimi VO. Sequence analysis of genes mediating extended-spectrum beta-lactamase (ESBL) production in isolates of Enterobacteriaceae in a Lagos Teaching Hospital, Nigeria. BMC Infect Dis. 2015;15(1):259. https://doi.org/10.1186/s12879-015-1005-x

38. Adesoji AT, Ogunjobi AA. Detection of extended spectrum beta-lactamases resistance genes among bacteria isolated from selected drinking water distribution channels in Southwestern Nigeria. BioMed Res Int. 2016;2016:1-9. https://doi.org/10.1155/2016/7149295

39. Aernan PT, Umeh EU. Molecular characterization of Extended-Spectrum BetaLactamase (ESBLs) genes in Pseudomonas aeruginosa from pregnant women attending a Tertiary Health Care Centre in Makurdi, Central Nigeria. Int J Sci Res Pub [serial online]. 2016 [cited 2019 Feb 6];6(10):19-25. Available from: http:// www.ijsrp.org/research-paper-1016.php?rp=P585866

40. Afiukwa A, Ngozi F, Iroha I, et al. First report of blaCTX-M-15 Extended Spectrum Beta-Lactamase (ESBL) producing E. coli isolated from cloacal swabs of birds in South Eastern Nigeria. Int Arch BioMed Clin Res. 2016;2(2):35-39. https://doi. org/10.21276/iabcr.2016.2.2.8

41. Mohammed Y. Characterization of extended- spectrum beta-lactamase from Escherichia coli and Klebsiella species from North Eastern Nigeria. J Clin Res [serial online]. 2016 [cited 2019 Feb 5]. Available from: http://jcdr.net/article fulltext. asp?issn=0973-709x \&year $=2016 \&$ volume $=10 \&$ issue $=2 \&$ page $=D C 07 \& i s s n=0973-$ $709 \times \& i d=7254$

42. Odewale G, Adefioye OJ, Ojo J, Adewumi FA, Olowe OA. Multidrug resistance of Acinetobacter baumannii in Ladoke Akintola University Teaching Hospital, Osogbo, Nigeria. Europe J Microbiol Immunol. 2016;6(3):238-243. https://doi. org/10.1556/1886.2015.00018

43. Ojo OE, Schwarz S, Michael GB. Detection and characterization of extendedspectrum $\beta$-lactamase-producing Escherichia coli from chicken production chains in Nigeria. Vet Microbiol. 2016;194:62-68. https://doi.org/10.1016/j.vetmic.2016. 04.022

44. Onyenwe NE. Molecular characterization of some multi-drug resistant Salmonella enterica of human origin in Southeast, Nigeria. MSc thesis. Ibadan: University of Ibadan, 2016; p. 1-174.

45. Alabi OS, Mendonça N, Adeleke OE, Da Silva GJ. Molecular screening of antibiotic resistant determinants among multidrug-resistant clinical isolates of Proteus resistant determinants among multidrug-resistant clinical isolates of Proteus
mirabilis from SouthWest Nigeria. Afr Health Sci. 2017;17(2):356. https://doi. mirabilis from SouthWest

46. Obasi A, Nwachukwu S, Ugoji E, et al. Extended-spectrum $\beta$-lactamase-producing Klebsiella pneumoniae from pharmaceutical wastewaters in South-Western Nigeria. Microb Drug Resist. 2017;23(8):1013-1018. https://doi.org/10.1089/ mdr.2016.0269

47. Olatunji MK, Olayemi A, Jimoh F. Distribution profile of Extended Spectrum Beta Lactamase (ESBL) producing Escherichia coli isolates from Asa River (Nigeria). Appl Sci Env Mgt. 2017;20(4):973. https://doi.org/10.4314/jasem.v20i4.9

48. Thonda O, Oluduro A. Molecular characterization of ESBLs genes among multidrug resistant Klebsiella species in Ile-lfe South-West, Nigeria. J Adv Microbiol. 2017;7(2):1-9. https://doi.org/10.9734/JAMB/2017/37925

49. Adelowo OO, Caucci S, Banjo OA, et al. Extended Spectrum Beta-Lactamase (ESBL)-producing bacteria isolated from hospital wastewaters, rivers and aquaculture sources in Nigeria. Env Sci Pol Res. 2018;25(3):2744-2755. https:// doi.org/10.1007/s11356-017-0686-7

50. Adeluola AO, Oyedeji KS, Mendie UE, Johnson JR, Porter JR. Detection, inhibition and molecular analysis of multidrug resistant aerobic gram-negative clinical isolates from a tertiary hospital in Nigeria. Afr J Biomed Res. 2018 [cited 2019 Feb 5];21(1):15-21. Available from: https://www.ajol.info/index.php/ajbr/article/view/165960

51. Akinbami OR, Olofinsae S, Ayeni FA. Prevalence of extended spectrum beta lactamase and plasmid mediated quinolone resistant genes in strains of Klebsiella pneumonia Morganella morganii, Leclercia adecarboxylata and Citrobacter pneumonia, Morganella morganii, Leclercia adecarboxylata and Citrobacter
freundii isolated from poultry in South Western Nigeria. Peer J. 2018;6:e5053. https://doi.org/10.7717/peerj.5053 
52. Okpara EO, Ojo OE, Awoyomi OJ, Dipeolu MA, Oyekunle MA, Schwarz S Antimicrobial usage and presence of extended-spectrum $\beta$-lactamase-producing Enterobacteriaceae in animal-rearing households of selected rural and peri-urban Enterobacteriaceae in animal-rearing households of selected rural and peri-urban
communities. Vet Microb. 2018:218:31-39. https://doi.org/10.1016/j.vetmic. 2018.03.013

53. Olowo-okere A, Ibrahim YKE, Olayinka BO. Molecular characterisation of extended-spectrum $\beta$-lactamase-producing Gram-negative bacterial isolates from Antimicrob Resist. 2018;14:85-89. https://doi.org/10.1186/s12941-019-0342-9

54. Adesina T, Nwinyi O, De N, Akinnola O, Omonigbehin E. First detection of carbapenem-resistant Escherichia fergusonii strains harbouring beta-lactamase genes from clinical samples. Pathogens. 2019;8(4):164. https://doi.org/10.3390/ pathogens 8040164

55. Nwafia IN, Ohanu ME, Ebede SO, Ozumba UC. Molecular detection and antibiotic resistance pattern of extended-spectrum beta-lactamase producing Escherichia coli in a Tertiary Hospital in Enugu, Nigeria. Ann Clin Microbiol Antimicrob. 2019;18(1):41. https://doi.org/10.1186/s12941-019-0342-9

56. Tsaku PA, Ngwai YB, Pennap GRI, et al. Extended-spectrum beta-lactamaseproduction in Escherichia coli isolated from door handles in Nasarawa State University, Keffi, Nigeria. Heliyon. 2019;5(8):e02177. https://doi.org/10.1016/j. heliyon.2019.e02177

57. Igwe JC, Onaolapo JA, Kachallah M, et al. Molecular characterization of extended spectrum beta-lactamase genes in clinical Escherichia coli isolates. J Biomed Sc Eng. 2014;07(05):276-285. https://doi.org/10.4236/jbise.2014.75030

58. Ugwu IC. Characterization of avian pathogenic Escherichia coli and extended spectrum beta-lactamase producing Escherichia coli isolated from chickens in Enugu State, Nigeria. PhD thesis. Nsukka, Nigeria: University of Nigeria. 2015; $p$ $1-216$.

59. Brinkac LM, White R, D'Souza R, Nguyen K, Obaro SK, Fouts DE. Emergence of New Delhi Metallo- ${ }_{\mathrm{L}}$-Lactamase (NDM-5) in Klebsiella quasipneumoniae from Neonates in a Nigerian Hospital. mSphere. 2019;4(2):10. https://doi.org/10.1128/ mSphere.00685-18

60. Olaitan AO, Berrazeg M, Fagade OE, Adelowo OO, Alli JA, Rolain JM. Emergence of multidrug-resistant Acinetobacter baumannii producing OXA-23 carbapenemase, Nigeria. Int J Infect Dis. 2013;17(6):e469-e470. https://doi.org/10.1016/j.ijid. 2012.12.008

61. Ogbolu DO, Webber MA. High-level and novel mechanisms of carbapenem resistance in Gram-negative bacteria from tertiary hospitals in Nigeria. Int resistance in Gram-negative bacteria from tertiary hospitals in Nigeria. Int Antimicrob A

62. Mohammed Y, Zailani SB, Onipede AO. Characterization of KPC, NDM and VIM type carbapenem resistance Enterobacteriaceae from North Eastern Nigeria Biosci Med. 2015;03(11):100-107. https://doi.org/10.4236/jbm.2015.311013

63. Walkty A, Gilmour $M$, Simner $P$, et al. Isolation of multiple carbapenemaseproducing Gram-negative bacilli from a patient recently hospitalized in Nigeria. Diagn Microbiol Infect Dis. 2015;81(4):296-298. https://doi.org/10.1016/j. diagmicrobio.2015.01.005

64. Uwaezuoke NS, Kieffer N, Iregbu KC, Nordmann P. First report of OXA-181 and NDM-1 from a clinical Klebsiella pneumoniae isolate from Nigeria. Int J Infect Dis. 2017;61:1-2. https://doi.org/10.1016/j.ijid.2017.05.004

65. Adelowo OO, Vollmers J, Mäusezahl I, Kaster A-K, Müller JA. Detection of the carbapenemase gene blaVIM-5 in members of the Pseudomonas putida group isolated from polluted Nigerian wetlands. Sci Rep. 2018;8(1):15116. https://doi. org/10.1038/s41598-018-33535-3

66. Zubair K, Iregbu K. Resistance pattern and detection of metallo-beta-lactamase genes in clinical isolates of Pseudomonas aeruginosa in a Central Nigeria. Nigeria J Clin Pract. 2018;21(2):176-182.

67. Iredell J, Brown J, Tagg K. Antibiotic resistance in Enterobacteriaceae: Mechanisms and clinical implications. BMJ. 2016;352:h6420. https://doi.org/10.1136/bmj. h6420

68. Ekwanzala MD, Dewar JB, Kamika I, Momba MNB. Systematic review in South Africa reveals antibiotic resistance genes shared between clinical and Africa reveals antibiotic resistance genes shared between clinical and environmental settings.

69. Liebana E, Carattoli A, Coque TM, et al. Public health risks of enterobacterial isolates producing extended-spectrum $\beta$-lactamases or AmpC $\beta$-lactamases in food and food-producing animals: An EU perspective of epidemiology, analytical methods, risk factors, and control options. Clin Infect Dis. 2013;56(7):1030-1037. methods, risk factors, and control op
https://doi.org/10.1093/cid/cis1043
70. Köck R, Daniels-Haardt I, Becker K, et al. Carbapenem-resistant Enterobacteriaceae in wildlife, food-producing, and companion animals: A systematic review. Clin Microbiol Infect. 2018;24(12):1241-1250. https://doi.org/10.1016/j.cmi.2018. 04.004

71. Storberg V. ESBL-producing Enterobacteriaceae in Africa - A non-systematic literature review of research published 2008-2012. Infect Ecol Epidemiol. 2014;4(1):20342. https://doi.org/10.3402/iee.v4.20342

72. Sonda $T$, Kumburu $H$, Van Zwetselaar $M$, et al. Meta-analysis of proportion estimates of extended-spectrum-beta-lactamase-producing Enterobacteriaceae in East Africa hospitals. Antimicrob Resist Infect Control. 2016;5(1):18. https://doi. org/10.1186/s13756-016-0117-4

73. Seni J, Moremi N, Matee M, et al. Preliminary insights into the occurrence of similar clones of extended-spectrum beta-lactamase-producing bacteria in humans, animals and the environment in Tanzania: A systematic review and metaanalysis between 2005 and 2016. Zoonoses Public Health. 2018;65(1):1-10. https://doi.org/10.1111/zph.12387

74. Collignon P, McEwen S. One health - Its importance in helping to better control antimicrobial resistance. Trop Med Infect Dis. 2019;4(1):22. https://doi. org/10.3390/tropicalmed4010022

75. Nakaye M, Bwanga F, Itabangi H, Stanley I, Bashir M, Bazira J. AmpC-Beta actamases among Enterobacteriaceae isolated at a tertiary hospital, South Western Uganda. British Biotech J. 2014;4(9):1026-1036. https://doi.org/ 10.9734/BBJ/2014/10570

76. Guerra B, Fischer J, Helmuth R. An emerging public health problem: Acquired carbapenemase-producing microorganisms are present in food-producing animals, their environment, companion animals and wild birds. Vet Microbiol. 2014;171(3-4):290-297. https://doi.org/10.1016/j.vetmic.2014.02.001

77. Manenzhe RI, Zar HJ, Nicol MP, Kaba M. The spread of carbapenemase-producing bacteria in Africa: A systematic review. J Antimicrob Chemother. 2015;70(1): 23-40. https://doi.org/10.1093/jac/dku356

78. Sekyere JO, Govinden U, Essack S. The molecular epidemiology and genetic environment of Carbapenemases detected in Africa. Microb Drug Resist. 2016;22(1):59-68. https://doi.org/10.1089/mdr.2015.0053

79. Cantón R, González-Alba JM, Galán JC. CTX-M enzymes: Origin and diffusion. Front Microbiol. 2012;3:110. https://doi.org/10.3389/fmicb.2012.00110

80. Cantón R, Coque TM. The CTX-M $\beta$-lactamase pandemic. Curr Opin Microbiol. 2006;9(5):466-475. https://doi.org/10.1016/j.mib.2006.08.011

81. Peirano G, Pitout JDD. Molecular epidemiology of Escherichia coli producing CTX-M $\beta$-lactamases: The worldwide emergence of clone ST131 O25:H4. Int Antimicrob Agents. 2010;35(4):316-321. https://doi.org/10.1016/j.ijantimicag. 2009.11.003

82. Bevan ER, Jones AM, Hawkey PM. Global epidemiology of CTX-M $\beta$-lactamases: Temporal and geographical shifts in genotype. J Antimicrob Chemother. 2017;72(8):2145-2155. https://doi.org/10.1093/jac/dkx146

83. Liakopoulos A, Mevius D, Ceccarelli D. A review of SHV Extended-Spectrum $\beta$-Lactamases: Neglected yet ubiquitous. Front Microbiol. 2016;7:1374. https:// doi.org/10.3389/fmicb.2016.01374

84. Fam N, Gamal D, El Said M, et al. Prevalence of plasmid-mediated ampC genes in clinical isolates of Enterobacteriaceae from Cairo, Egypt. British Microbiol Res $J$ 2013;3(4):525-537. https://doi.org/10.9734/BMRJ/2013/4653

85. Pitout JDD, Gregson DB, Church D, Laupland KB. Population-based laboratory surveillance for AmpC $\beta$-Lactamase-producing Escherichia coli, Calgary. Emerg Infect Dis. 2007;13(3):443-448. https://doi.org/10.3201/eid1303.060447

86. Eskandari-Nasab E, Moghadampour M, Tahmasebi A. Prevalence of blaCTX-M gene among extended-spectrum $\beta$-lactamases producing Klebsiella pneumoniae clinical isolates in Iran: A meta-analysis. Iran J Med Sci. 2018;43(4):8.

87. Karanika S, Karantanos T, Arvanitis M, Grigoras C, Mylonakis E. Fecal colonization with extended-spectrum beta-lactamase-Producing Enterobacteriaceae and risk factors among healthy individuals: A systematic review and metaanalysis. Clin Infect Dis. 2016;63(3):310-318. https://doi.org/10.1093/cid/ciw283

88. Altayb HN, Siddig MAM, Amin NME, Hashim Al, Mukhtar M. Molecula characterization of CTX-M ESBLs among pathogenic Enterobacteriaceae isolated from different regions in Sudan. Glob Adv Res J Microbiol. 2018;7(2):40-46.

89. Adesokan HK, Akanbi IO, Akanbi IM, Obaweda RA. Pattern of antimicrobial usage in livestock animals in south-western Nigeria: The need for alternative plans. Onderstepoort J Vet Res. 2015;82(1):816. https://doi.org/10.4102/ojvr. plans. Onders
v82i1.816 